\title{
FACTORS AFFECTING GARLIC PRODUCTION IN LATVIA
}

Aina Muska ${ }^{1}$, Dr.oec., associate professor; Evita Saksone ${ }^{2}$, MBA

${ }_{1,2}$ Latvia University of Life Sciences and Technologies

\begin{abstract}
The population of Latvia is increasingly interested in the production of garlic both for self-consumption and for sales in the market. The research puts forward the following hypothesis: garlic production is affected by economic and production factors of diverse significance. The research aims to examine the factors affecting the production of garlic in Latvia. The specific research tasks are as follows: (1) to give the characteristics of garlic production in Latvia; (2) to identify and assess the factors affecting the production of garlic in Latvia. The research has found that in Latvia, garlic was grown in small areas as an auxiliary crop, mainly in Zemgale region representing $54 \%$ of the total garlic area as well as in Pieriga region (16\%), as garlic is a resource-intensive crop and sensitive to weather conditions and soil composition. Consequently, soils tests have to be done and a number of garlic varieties have to be field-tested for several years before starting growing this crop in order to identify the best variety for the field and the best garlic growing technology. Five most significant factors affecting garlic production in Latvia were as follows: (1) large financial investments are needed to start growing garlic (expert rating 0.84), (2) quality and availability of planting material $(0.66)$, (3) soil composition (0.50), (4) weather conditions (0.47) and (5) labour intensity (0.44). In the analysis period of 2013-2016, Latvia annually imported approximately $900 \mathrm{t}$ of garlic, i.e. more that the country produced this commodity. The Netherlands and Spain were the most significant importers of garlic into Latvia, accounting for more than $85 \%$ of the total imports of garlic.
\end{abstract}

Key words: garlic, yield, factors, open field vegetables.

JEL code: Q13, M11, O13.

\section{Introduction}

The European Commission (2017) has stressed in its communication "The Future of Food and Farming" that "unlike most other economic sectors, farming is strongly affected by the weather; it is also frequently tested by volatile prices, natural disasters, pests and diseases - with the result that, every year, at least $20 \%$ of farmers lose more than $30 \%$ of their income compared with the average of the last three years... Climate change threatens to make all of the above-mentioned problems weigh more heavily". The Common Agricultural Policy (CAP) is one of the EU action policies, the purpose of which is to ensure what the population expects in relation to food; therefore, in its communication the European Commission (2017) also stressed that the CAP should continue to support production with specific and valuable characteristics through Rural Development as well as to promote and improve its international recognition. One more function of the CAP is to ensure nutritious valuable products are easily available for EU citizens (European Commission, 2017). The authors of the paper believe that one of the most valuable agricultural products - with ancient growing traditions in the world and Europe - is garlic. During the interviews conducted by the authors, the garlic producers and experts also pointed out the growing interest of the population of Latvia in the production of garlic for both self-consumption and the market. In Latvia, the output of garlic fluctuated over the analysis period owing to various circumstances and factors. Even though there are all the necessary preconditions for garlic production in Latvia, the data on the area under garlic and the output and average yield of garlic indicate that there are factors hindering domestic garlic producers from approaching the levels reported in the largest garlic producers: China, India, Spain etc.

The research hypothesis is as follows: garlic production is affected by economic and production factors of diverse significance. The research aims to examine the factors affecting the production of garlic in Latvia.

\footnotetext{
${ }^{1}$ Corresponding author: Aina.Muska@llu.Iv
} 
The specific research tasks are as follows: (1) to give the characteristics of garlic production in Latvia; (2) to identify and assess the factors affecting the production of garlic in Latvia.

The research employed general scientific methods (monographic, graphical, logical construction and synthesis and analysis), sociological methods (document analysis, expert surveying and interviewing) and statistical analysis (time series analysis and Pearson correlation analysis). The period of 2013-2017 was chosen to identify trends in garlic production.

The research used the data of the Food and Agriculture Organization of the United Nation (FAO), the Central Statistical Bureau (CSB) of Latvia, the Latvian Rural Advisory and Training Centre, the State Plant Protection Service and the Rural Support Service, publications by the Ministry of Agriculture as well as a research study by I.Missa (2013) on garlic production under the conditions in Latvia. A number of garlic producers and experts were interviewed in Latvia to acquire primary information.

\section{Research results and discussion}

\section{Garlic area analysis}

The world leader in garlic production in terms of cropped area and output is China. The output of garlic in China is almost 15-fold higher than that India, which is the second largest garlic producer in the world, and more than 60 -fold higher than that in the European Union as a whole. Chinese garlic producers, having favourable climatic conditions, suited soils and experience, applying high fertiliser rates and practicing a two-fold higher plant density, acquire higher garlic yields - 27 t/ha (2017) (Missa, 2013; FAOSTAT, [s.a.]).

Spain is the largest producer of garlic in the EU, accounting for more than half of the total EU output of garlic. In 2017, Spain produced 274712 t of garlic or $87 \%$ of the total EU output, while the garlic area was 26630 ha or $56 \%$ of the total area cropped with garlic in the EU (FAOSTAT, [s.a.]).

In Latvia, garlic is mainly grown as an auxiliary crop on farms, household plots and family farms. In 2018 in Latvia, according to the Register of Fruit, Berry and Vegetable Producers of the State Plant Protection Service, there were 81 garlic producers: 44 private persons, 15 family farms, 12 farms and 10 commercial farms. The data of the register are incomplete, as the data are based on the data submitted to the Rural Support Service by individuals who want to receive area payments (State Plant Protection Service, [s.a.]). In 2013, according to the FAO, garlic was produced in Latvia in an area of 177 ha (Figure 1), while the area declared for the area payment scheme was 60.28 ha or only a third of the total (RSS, [s.a.]). In 2014, $44 \%$ of the reported area under garlic (112 ha) was declared for the scheme; in 2015 it was $31 \%$, while in $2016-46 \%$. In 2017, 135.5 ha under garlic were declared for the scheme, which was the largest area in the analysis period, yet it was only $27 \%$ of the area reported by the FAO (RSS, [s.a.]). Horticultural expert M.Gailite (2017) explains the difference in data by the fact that most of the area under garlic is comprised of small plots, up to 0.3 ha in size, which are managed by a family.

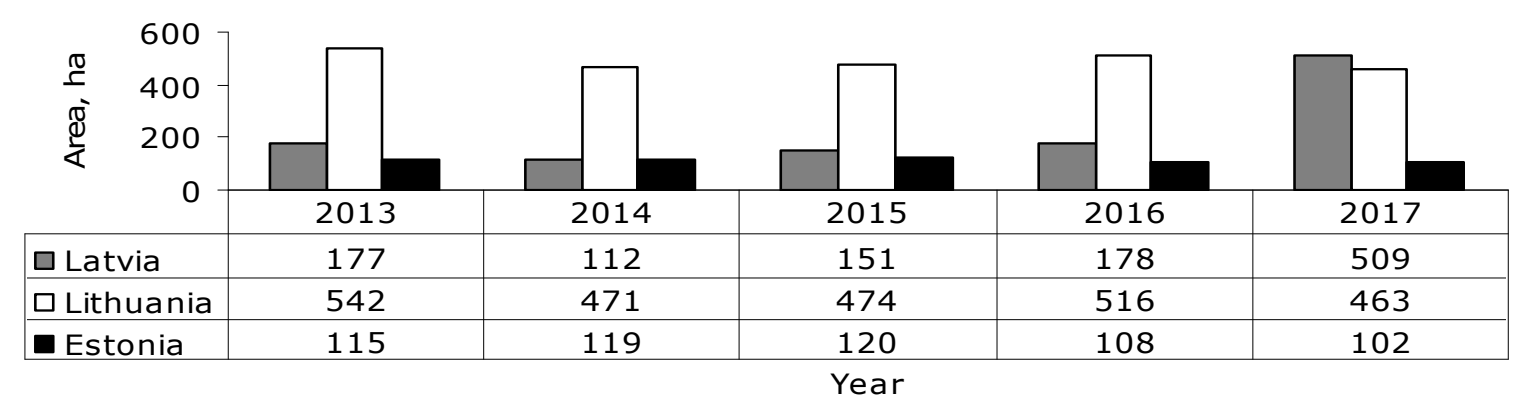

Source: FAOSTAT, [s.a.]

Fig. 1. Garlic areas in the Baltic States in the period 2013-2017, ha 
As shown in Figure 1, the garlic area in Latvia rose by $186 \%$ in 2017 compared with 2016, which was a considerable increase, yet the garlic area represented only $6 \%$ of the total area cropped with open field vegetables. Up to 2017 in Latvia, just like in Estonia, garlic has been grown in small areas. A comparison of the garlic areas between Lithuania and Latvia reveals that before 2017, the garlic area was 3-4-fold larger in Lithuania than in Latvia, and No significant changes occurred in the analysis period.

\section{Analysis of the factors affecting garlic production}

The authors wished to examine the key factors affecting garlic production in Latvia. Based on an analysis of information sources, the authors identified seven factors (Table 1). To assess the factors, the authors involved five industry experts and garlic producers. The influence of a factor was rated on a 3-point scale ( 1 - insignificant influence; 2 - moderate influence; 3 - significant influence), while the probability of factor change was rated on a 5-point scale (with 1 being the lowest probability; 5 - the highest). Factor significance was calculated by multiplying the influence of a factor by the probability of change for the corresponding factor and then dividing it by the sum of influence ratings (Table 1 ).

Table 1

Ratings of the factors affecting garlic production in Latvia

\begin{tabular}{|l|c|c|c|}
\hline \multicolumn{1}{|c|}{ Factors } & $\begin{array}{c}\text { Factor influence } \\
\text { rating (1-3 } \\
\text { points) }\end{array}$ & $\begin{array}{c}\text { Average expert rating of } \\
\text { factor change probability } \\
\text { (1-5 points) }\end{array}$ & $\begin{array}{c}\text { Factor } \\
\text { significance }\end{array}$ \\
\hline Large financial investments & 2. & 3. & $4 .=2 . \times 3 . / \Sigma 2$. \\
\hline $\begin{array}{l}\text { Quality and availability of planting } \\
\text { material }\end{array}$ & 3 & 4.5 & $\mathbf{0 . 8 4}$ \\
\hline Soil composition & 3 & 3.5 & $\mathbf{0 . 6 6}$ \\
\hline Weather conditions & 2 & 4 & $\mathbf{0 . 5 0}$ \\
\hline High proportion of manual work & 3 & 2.5 & $\mathbf{0 . 4 7}$ \\
\hline Garlic imports & 2 & 3.5 & $\mathbf{0 . 4 4}$ \\
\hline Removal of flower stalks & 2 & 2 & $\mathbf{0 . 2 5}$ \\
\hline \multicolumn{1}{|c|}{ TOTAL } & 16 & 2.5 & $\mathbf{0 . 1 6}$ \\
\hline
\end{tabular}

Source: authors' research

The research results showed that the most significant factor affecting garlic production in Latvia was large financial investments (0.84) needed upon starting growing the garlic - for buying planting material and machinery. According to various literature sources, the amount of planting material needed for garlic production is in the range of 0.7-1.8 t/ha. Based on expert recommendations, the Latvian Rural Advisory and Training Centre (LRATC) (2014-2018) has estimates it at $1.0 \mathrm{t} / \mathrm{ha}$. In the interviews, some garlic producers noted even a higher planting rate $-1.4-1.8 \mathrm{t} / \mathrm{ha}$. The wide range of the planting rate for garlic could be explained by the size of a clove, which is affected by the garlic variety, and planting spacing.

In Latvia, No garlic price monitoring is carried out. The research used information provided by advertisement websites as well as data used by the LRATC. An analysis of the LRATC data (2014-2018) revealed that the purchase price rose by $4.3 \%$ from $4.70 \mathrm{EUR} / \mathrm{kg}$ in the period $2013-2016$ to $4.90 \mathrm{EUR} / \mathrm{kg}$ in 2017. In the interviews, the garlic growers revealed that high-quality planting material cost 4.005.50 EUR/kg in the analysis period. In 2018, according to the Baltic Garlic Growers Association ([s.a].a), the price of planting material, depending on the size of a clove, ranged from $3.10 \mathrm{EUR} / \mathrm{kg}$ (sized 40/50 $\mathrm{mm}$ ) to $6.10 \mathrm{EUR} / \mathrm{kg}$ (sized $60 \mathrm{~mm}+$ ) (VAT (21\%) and transport cost excluded). The price of organic planting material was in the range of 7.90-10.35 EUR/kg (VAT (21 \%) and transport cost excluded). 
Assuming that the planting rate is in the range of $0.7-1.8 \mathrm{t} / \mathrm{ha}$ and the average purchase price is 4.90 EUR/kg, the cost of planting material ranges from 3430 up to 8820 EUR/ha.

Growing garlic in a very large area requires machinery, as many agricultural operations have to be performed in a short period, and, if the work is large, it is almost impossible to mobilise many employees for a short period. Besides, weather conditions affect the production of garlic (Missa, 2013).

The machinery needed for garlic production could be bought gradually, in line with the financial capacity of the producer. However, producing garlic in a long-term and in a large area requires large investments. Examining the machinery, the authors found that both garlic clove splitting machines and planting machines and garlic harvesters could be bought in Latvia (Baltic Garlic Growers Association, [s.a.]b). The authors estimated that at least EUR 21 000-28 000 should be invested: the cost of a splitting machine is about EUR 3000 (Vitlok B-18), the cost of a garlic planting machine ranges from EUR 1350 (Renal Sdc 001) to EUR 8432 (JJ BorchPLMA-2), the cost of a garlic harvester is much higher - EUR 16500 (Spain firm "ZOCAPI" harvester) (VBC Group, [s.a.]; Baltic Garlic Growers Association, [s.a.]b). According to the research by I.Missa (2013), more than EUR 30000 have to be invested in machinery to mechanise the garlic production process.

The purchase of garlic planting material is problematic not only because of its high cost but also because No certified planting material is available at seed shops. In the interviews, the garlic growers admitted that upon starting growing garlic, they bought a small amount of high-quality certified planting material from official sellers. The remaining amount of planting material they sought to produce themselves.

The research confirmed that the next most significant factor was quality and availability of planting material (0.66). In Latvia, as pointed out by I.Missa (2013), it was difficult to acquire planting material being not infected with grey mould (Botrytis cinerea) or other moulds, mites, viruses or nematodes. According to calculations by I.Missa (2013), the loss because of discarding planting material might exceed $50 \%$. This decreases the amount of planting material and increases the cost of it.

In the period 2013-2015, a research study on domestic garlic producers was done in Lithuania. The research study aimed to compare national garlic varieties with foreign ones and analyse the varieties in terms of productivity and garlic bulb sizes. The research study found that the local variety Ziemiai demonstrated the highest yield, reaching even 12.9 t/ha. In contrast, the garlic varieties imported from Spain, Czech Republic and China performed the worst: 4.5 -9.4 t/ha. The research study has confirmed the findings made by other authors - garlic yields are affected by climatic and environmental conditions, and it is a reason why national varieties of garlic are better suited for the needs of production (Juskeviciene et al., 2016). In the interviews, the garlic growers pointed out that upon starting growing garlic in large quantities, the best option was to try several varieties for a number of years in order to identify the best variety and the best growing technology. I.Missa (2013) believed that the garlic grown in Scandinavia, Great Britain, France, Poland and the Czech Republic was suited for being grown in Latvia.

The production of garlic is affected by soil composition (expert rating 0.50 ) as well. The preconditions for high garlic yields are as follows: a lot of sunlight, enough moisture, a humus-rich, medium-heavy and well-structured soil with a thick arable layer. Besides, it is advised not to grow garlic in the same field earlier than after 3-4 years (Missa, 2013). This is a reason why No farms have presently specialised in garlic production. Since the production of garlic is affected by both the quality of planting material and soil composition, the authors believe that upon starting growing garlic, soils tests have to be done and a number of garlic varieties have to be field-tested in order to identify the best variety for the field and the best garlic growing technology. 
An analysis of the Rural Support Service data on the garlic area declared in 2018 showed that the largest areas were reported in Zemgale region as well as Pieriga region (Figure 2). The garlic producers explained it by fertile soils and appropriate weather conditions.


\section{Source: Rural Support Service, [s.a.]; CSB, [s.a.]}

Fig. 2. Percentage breakdown of the areas cropped with garlic and open field vegetables by region in Latvia

An analysis of the data on the areas under open field vegetables in the regions of Latvia revealed that the same two regions dominated - Zemgale and Pieriga. According to the Ministry of Agriculture (2018), the entire area of Latvia is suited for vegetable production, yet the type of farms was determined by the sales market - mainly the vicinity of cities. To identify whether the garlic areas are related to the sales locations, the authors performed a correlation analysis. The dependent variables were as follows: (1) number of cities and towns in a municipality; (2) population at the beginning of the year; (3) population density in the municipality; and (4) distance to the regional centre. The p-values were above than 0.05 and the correlation coefficients were below 0.3 , which meant that there was No statistically significant correlation between the variables.

The third factor that considerably affected garlic producers was weather conditions. Frost in spring can affect garlic sprouts, which, in turn, affects the yield. Too wet conditions during harvest can contribute to rot and make post-harvest treatment complicated. In contrast, drought at the beginning of the vegetation season affects the ability of garlic to root and later the growth of it (Gailite, 2017). According to the Ministry of Agriculture (2018), farmers prefer growing the crops needing relatively simple technologies and not depending on meteorological conditions.

In 2014 in Latvia, weather conditions in winter (No snow) and spring (frost) were not favourable for the production of high-quality garlic; consequently, the average yield and output of garlic decreased (Figure 2) (MoA, 2015). The output of garlic was affected by a decrease in the area cropped with garlic in the country. 
Output and average yield of garlic and the annual changes therein in the Baltic States in the period 2013-20017

\begin{tabular}{|c|c|c|c|c|c|}
\hline Indicators & 2013 & 2014 & 2015 & 2016 & 2017 \\
\hline \multicolumn{6}{|c|}{ Latvia } \\
\hline Garlic output, tonnes & 524 & 129 & 680 & 610 & 1884 \\
\hline Annual change, \% & - & -75 & +427 & -10 & +209 \\
\hline Average garlic yield, cnt/ha & 29.6 & 11.5 & 45.0 & 34.3 & 37.0 \\
\hline Annual change, \% & - & -61 & +291 & -24 & +8 \\
\hline \multicolumn{6}{|c|}{ Lithuania } \\
\hline Garlic output, tonnes & 2024 & 1561 & 1503 & 1622 & 970 \\
\hline Average garlic yield, cnt/ha & 37.3 & 33.1 & 31.7 & 31.4 & 21.0 \\
\hline Annual change, $\%$ & - & -11 & -4 & -1 & -33 \\
\hline \multicolumn{6}{|c|}{ Estonia } \\
\hline Garlic output, tonnes & 206 & 148 & 300 & 185 & 356 \\
\hline Average garlic yield, cnt/ha & 17.9 & 12.4 & 25.0 & 17.1 & 35.0 \\
\hline Annual change, $\%$ & - & -31 & +102 & -32 & +105 \\
\hline
\end{tabular}

Source: FAOSTAT, [s.a.]; authors' calculations

In 2015, however, weather conditions were suitable for garlic production (MoA, 2016); consequently, the average yield of garlic considerably (almost 4-fold) as well as the output of garlic (5.3-fold) increased. The output of garlic increased also owing to an increase of the area under garlic by $35 \%$.

In 2016, despite an $18 \%$ increase in the garlic area, the output of garlic decreased by $10 \%$, which might be explained by long-lasting rainfalls in August, which did not allow harvesting high-quality garlic (MoA, 2107). The weather conditions affected the average yield of garlic, which decreased by $24 \%$.

Even though weather conditions in 2017 were not suitable for garlic production in Latvia (MoA, 2018), the output of garlic rose 3-fold because the area cropped with garlic increased 2.9-fold. The average yield of garlic rose by $8 \%$.

A comparison of the average yields of garlic among the Baltic States reveals that the average yield was lower in Estonia than in Latvia, yet the trend was similar. In her research, Vahejoe et al. (2011) found that the garlic yield in Estonia could considerably vary by variety and growth conditions and could reach 30$50 \mathrm{cnt} / \mathrm{ha}$. This means that only in 2017 average garlic yields were achieved in Estonia. In the analysis period in Lithuania, the average yield of garlic gradually decreased, and since 2015 it has been lower than that in Latvia.

According to I.Missa (2013), a normal garlic yield harvested under the conditions in Latvia could be in the range of 50-90 cnt/ha, which is 1.6-3-fold more than on average in the analysis period. If a garlic field is watered, according to I.Missa, one can harvest $150 \mathrm{cnt} / \mathrm{ha}$ of high-quality garlic.

A comparison of the average yield with the amount of planting material $(7-18 \mathrm{cnt} / \mathrm{ha})$ in the analysis period reveals that the yield is 2-6-fold higher than the amount of garlic planted, except for 2014 when the average yield was the lowest, and it was likely that garlic producers suffered losses. According to calculations by I.Missa (2013), a yield of $30 \mathrm{cnt} /$ ha or lower brings losses to garlic producers.

In the interview, LRATC specialist M.Narvils stressed that in view of the climatic conditions in Latvia, mulching the field could be a solution that positively affects garlic growth because it contributes to microbiological activity in soil and in a cold snowless winter garlic plantations are not damaged, while in 
hot summer the mulch keeps moisture. The application of mulch has not been sufficiently examined in Latvia.

The experts pointed out that garlic production is labour intensive. This might be one of the reasons why the garlic area in Latvia in the period 2013-2016 comprised only approximately $\mathbf{2} \%$ of the total area under open field vegetables. In 2017, the proportion rose to $6 \%$ (FAOSTAT, [s.a.]; CSB, [s.a.]).

According to calculations by I.Missa (2013), managing a hectare under garlic requires 400-500 hours of manual work (50-63 man-days), of which 100 hours (12-15 man-days) are required for preparing planting material, 200 hours (at least 25 man-days) for harvesting and post-harvest treatment. Soil tillage and transport by means of machinery requires 20-30 hours.

I.Missa (2013) also point out that if a lot of cloves have to be discarded, preparing planting material could require at least 240 hours or 30 man-days. This implies that managing a hectare under garlic could require more than 600 hours of manual work or 75 man-days. A mechanised process of garlic bulb splitting, depending on machinery, allows processing 250-1000 kg of garlic or 10 times more than an employee can do during a working day.

As pointed out by I.Missa (2013), planting garlic is worth mechanising only if a large area is involved because planting garlic by means of a potato planter decreases yield by up to $10 \%$, and only large-scale production makes the yield decrease insignificant relative to manual work input.

In the period 2013-2016, Latvia annually imported approximately $900 \mathrm{t}$ of garlic, which exceeded the annual output of it in the country. However, in 2014 Latvia imported seven times more garlic than it produced this product. In the analysis period, the imports of garlic were steady, and the Netherlands and Spain were the most significant importers of garlic into Latvia, accounting for more than $85 \%$ of the total imports of garlic. According to FAOSTAT ([s.a.]), the Netherlands, Spain as well as China and Argentine were the largest garlic exporters in the world. Garlic from China, however, was imported in small quantities.

Table 3

Imports of garlic in absolute and relative terms by country in Latvia in the period 2013-2016

\begin{tabular}{|l|c|c|c|c|c|c|c|c|}
\hline \multirow{2}{*}{ Countries } & \multicolumn{2}{|c|}{$\mathbf{2 0 1 3}$} & \multicolumn{2}{c|}{$\mathbf{2 0 1 4}$} & \multicolumn{2}{c|}{2016} \\
\cline { 2 - 10 } & $\begin{array}{c}\text { Quantity, } \\
\mathrm{t}\end{array}$ & Percentage & $\begin{array}{c}\text { Quantity, } \\
\mathrm{t}\end{array}$ & Percentage & $\begin{array}{c}\text { Quantity, } \\
\mathrm{t}\end{array}$ & Percentage & $\begin{array}{c}\text { Quantity, } \\
\mathrm{t}\end{array}$ & Percentage \\
\hline $\begin{array}{l}\text { Nether- } \\
\text { lands }\end{array}$ & 461 & 51.1 & 344 & 38.6 & 441 & 51.7 & 407 & 45.2 \\
\hline Spain & 316 & 35.0 & 417 & 46.7 & 317 & 37.2 & 384 & 42.7 \\
\hline Lithuania & 94 & 10.4 & 57 & 6.4 & 36 & 4.2 & 25 & 2.8 \\
\hline China & 21 & 2.3 & 51 & 5.7 & 17 & 2.0 & 16 & 1.8 \\
\hline Hungary & 3 & 0.3 & 9 & 1.0 & 9 & 1.1 & 20 & 2.2 \\
\hline Italy & 2 & 0.2 & 1 & 0.1 & 2 & 0.2 & 3 & 0.3 \\
\hline France & 2 & 0.2 & 1 & 0.1 & 1 & 0.1 & 0 & 0 \\
\hline Estonia & 2 & 0.2 & 0 & 0 & 0 & 0 & 1 & 0.1 \\
\hline $\begin{array}{l}\text { United } \\
\text { Kingdom }\end{array}$ & 1 & 0.1 & 1 & 0.1 & 0 & 0 & 0 & 0 \\
\hline Ukraine & 0 & 0 & 0 & 0 & 22 & 2.6 & 26 & 2.9 \\
\hline Sweden & 0 & 0 & 8 & 0.9 & 1 & 0.1 & 0 & 0 \\
\hline Poland & 0 & 0 & 3 & 0.3 & 7 & 0.8 & 18 & 2.0 \\
\hline $\begin{array}{l}\text { Total } \\
\text { imports }\end{array}$ & $\mathbf{9 0 2}$ & $\mathbf{1 0 0}$ & $\mathbf{8 9 2}$ & $\mathbf{1 0 0}$ & $\mathbf{8 5 3}$ & $\mathbf{1 0 0}$ & $\mathbf{9 0 0}$ & $\mathbf{1 0 0}$ \\
\hline Sourcerf & & & & & & \\
\hline
\end{tabular}

Source: FAOSTAT, [s.a.] 
Some part of the garlic produced in Latvia and, perhaps, imported garlic is exported. The exports of garlic are insignificant: 2-3-fold smaller than the imports; therefore, the balance of trade in garlic was negative in the entire analysis period: in monetary terms, the imports exceeded the exports more than two times. Most of the garlic (more than $80 \%$ in the analysis period) was exported to the neighbouring countries - Lithuania and Estonia.

As pointed out by I.Missa (2013), the problem of imports of garlic became urgent in Latvia in 2003 when the imports of cheap garlic rose and meat processors and other food producers in Latvia shifted to using dried garlic powder. In 2008 in the world, many countries increased garlic output, and it affected domestic garlic producers, as the garlic was exported at low prices to many countries, including Latvia.

A less significant factor affecting garlic production was removal of flower stalks (0.14). Flower stalks may not be cut too early in order not to infect the stalk cut, as well as not too late because it affects the yield of garlic. It is believed that the flower stalks not cut timely decrease the yield by $20-30 \%$; otherwise, nutrients accumulate in the flower stalks instead of the garlic bulb growing in soil (Missa, 2013). In the interviews, the garlic producers admitted that flower stalks had to be cut manually even in the case of conventional practices, and in the future this operation is not going to be mechanised. A solution could be the choice of garlic varieties not developing flower stalks, e.g. Germidour and Messidour.

\section{Conclusions, proposals, recommendations}

1) In Latvia, garlic was grown in small areas as an auxiliary crop, mainly in Zemgale region as well as in Pieriga region, as garlic is a resource-intensive crop and sensitive to weather conditions and soil composition. Consequently, soils tests have to be done and a number of garlic varieties have to be field-tested for several years before starting growing this crop in order to determine the best variety for the field and the best garlic growing technology.

2) In the analysis period of 2013-2016, Latvia annually imported approximately $900 \mathrm{t}$ of garlic, i.e. more that the country produced this commodity. The Netherlands and Spain were the most significant importers of garlic into Latvia, accounting for more than $85 \%$ of the total imports of garlic.

3) Five most significant factors affecting garlic production in Latvia were as follows: (1) large financial investments are needed to start growing garlic (expert rating 0.84), (2) quality and availability of planting material (0.66), (3) soil composition (0.50), (4) weather conditions $(0.47)$ and (5) labour intensity (0.44).

4) In order for garlic production to become a prospective agricultural activity, current and future garlic producers have to be educated on the specifics of garlic production and the key factors.

5) National data on garlic areas and yields are incomplete; therefore, the Baltic Garlic Growers Association could assume responsibility for collecting relevant statistics.

\section{Bibliography}

1. Baltic Garlic Growers Association ([s.a.]a) Garlic Planting Material Prices in 2018. Retrieved: http://www.bgga.Iv/node/83. Access: 02.02.2019.

2. Baltic Garlic Growers Association ([s.a.]b) Machinery and Equipment for Garlic Production. Retrieved: http://www.bgga.Iv/node/53. Access: 02.02.2019.

3. Central Statistical Bureau of Latvia (CSB) ([s.a.]). Statistics Database. Retrieved: https://www.csb.gov.Iv/en/statistika/db. Access: 02.02.2019. (Tables ISG040, GZG011, LAG030)

4. Diezina, S. (2015). Ziemas kiplokus audzet ir izdevigi, tacu jarekinas ar lieliem ieguldijumiem (Winter Garlic Production if Profitable, yet Large Investment is Needed). Retrieved: http://www.la.Iv/garsaugu-karalisvisrentablakais. Access: 02.02.2019.

5. European Commission (2017). Communication from the Commission to the European Parliament, the Council, the European Economic and Social Committee and the Committee of the Regions "The Future of Food and Farming". Brisele, 29.11.2017. COM(2017) 713. Retrieved: https://ec.europa.eu/agriculture/sites/agriculture/files/future-ofcap/future_of_food_and_farming_communication_Iv.pdf. Access: 02.02.2019. 
6. FAOSTAT ([s.a.]). Data. Retrieved: http://www.fao.org/faostat/en/\#data. Access: 02.02.2019.

7. Gailite, M. (2017), Pasaules kiploku tirgus ietekme cenas Latvija (World Garlic Market Affects Prices in Latvia). AGRO 2017, No. 4, pp. 86-87.

8. Juskeviciene, D., Karkleliene, R., Radevicius, A., Sasnauskas, A. (2016). Productivity and Morphological Features of Garlic (Allium Sativum L.) Grown in Lithuania. Agriculture\& Forestry 2016, No. 62, pp. 109-116.

9. Latvian Rural Advisory and Training Centre (LRATC) (2014). Bruto seguma aprekins zemnieku saimniecibai 2013.gada (Contribution Margin Calculations for a Farm in 2013). Retrieved: http://new.Ilkc.Iv/sites/default/files/baskik_p/pielikumi/brutosegums2013.gada_.pdf. Access: 02.02.2019.

10. Latvian Rural Advisory and Training Centre (LRATC) (2015). Bruto seguma aprekins zemnieku saimniecibai 2014.gada (Contribution Margin Calculations for a Farm in 2014). Retrieved: http://new.llkc.lv/sites/default/files/baskik_p/pielikumi/bruto_segums_internetam_mb.pdf. Access: 02.02.2019.

11. Latvian Rural Advisory and Training Centre (LRATC) (2016). Contribution Margins. Garlic (Winter). 2015. Retrieved: http://new.llkc.lv/sites/default/files/baskik_p/pielikumi/kiploki_3.pdf. Access: 02.02.2019.

12. Latvian Rural Advisory and Training Centre (LRATC) (2017). Contribution Margins. Garlic (Winter). 2016. Retrieved: http://new.Ilkc.Iv/sites/default/files/baskik_p/pielikumi/kiploki_5.pdf. Access: 02.02.2019.

13. Latvian Rural Advisory and Training Centre (LRATC) (2018). Contribution Margins. Garlic (Winter). 2017. Retrieved: http://new.Ilkc.Iv/sites/default/files/baskik_p/pielikumi/kiploki_ziemas_0.pdf. Access: 02.02.2019.

14. Rural Support Service (RSS) ([s.a.]). Statistika. Platibu maksajumi (Statistics. Area Payments). Retrieved: http://www.lad.gov.Iv/lv/statistika/platibu-maksajumi/. Access: 02.02.2019.

15. Missa, I. (2013). Kiploku audzesana Latvijas apstaklos (Garlic Production under the Conditions in Latvia). Ozolnieki: Latvian Rural Advisory and Training Centre Ltd, 51 p.

16. Vahejoe K., Luik H., Karp K., Poldma P. (2011). Darzkopibas rokasgramata (burkani, kiploki, dobju gurki, zemenes, darza mellenes, upenes) (Horticulture Handbook (Carrot, Garlic, Cucumber, Strawberry, Garden Blueberry, Blackcurrant)). Retrieved: http://www.apesnovads.Iv/wpcontent/uploads/2012/03/D \%C4 \%81rzkop \%C4 \%ABbas-rokasgr \%C4 \%81mata.pdf. Access: 02.02.2019.

17. State Plant Protection Service (SPPS) ([s.a.]). Auglkoku, ogulaju un darzenu audzetaju registrs (Register of Fruit, Berry and Vegetable Producers). Retrieved: http://www.vaad.gov.Iv/sakums/registri/audzetaju-registrs.aspx. Access: 02.02.2019.

18. VBC Group ([s.a.]). Sejmasinas stadisanai (Sowing Machines for Planting). Retrieved: http://www.vbc.Iv/sejmasinas_stadisana. Access: 11.27.2018.

19. Ministry of Agriculture of the Republic of Latvia (MoA) (2015). Latvijas lauksaimnieciba 2015 (Agriculture of Latvia 2015). Retrieved: https://www.zm.gov.Iv/public/files/CMS_Static_Page_Doc/00/00/00/63/66/LS_gadazinojums_2015.pdf. Access: 02.02.2019.

20. Ministry of Agriculture of the Republic of Latvia (MoA) (2016). Latvijas lauksaimnieciba 2016 (Agriculture of Latvia 2016). Retrieved: https://www.zm.gov.Iv/public/files/CMS_Static_Page_Doc/00/00/00/90/30/fs01usersLinda.BirinaDesktopAA2016_lauksaimniecibasgadazinojums.pdf. Access: 02.02.2019.

21. Ministry of Agriculture of the Republic of Latvia (MoA) (2017). Latvijas lauksaimnieciba 2017 (Agriculture of Latvia 2017). Retrieved: https://www.zm.gov.Iv/public/files/CMS_Static_Page_Doc/00/00/01/10/04/fs01usersLinda.BirinaDesktopAA2017_lauksaimniecibasgadazinojums.pdf. Access: 02.02.2019.

22. Ministry of Agriculture of the Republic of Latvia (MoA) (2018). Latvijas lauksaimnieciba 2018 (Agriculture of Latvia 2018). Retrieved: https://www.zm.gov.Iv/public/files/CMS_Static_Page_Doc/00/00/01/33/19/Gadazinojums.pdf. Access: 02.02.2019. 